\title{
Effectiveness of the Board of Commissioners Role: Review of Resources Dependence Theory
}

\section{Makaryanawati $^{1}$, Sriyani Mentari ${ }^{2}$, Fatmawati Zahroh ${ }^{3}$ and Ria Zulkha Ermayda ${ }^{4}$}

\author{
${ }^{1}$ Universitas Negeri Malang, Indonesia, e-mail: makaryanawati@gmail.com \\ ${ }^{2}$ Universitas Negeri Malang, Indonesia \\ ${ }^{3}$ Universitas Negeri Malang, Indonesia \\ ${ }^{4}$ Universitas Negeri Malang, Indonesia
}

\begin{abstract}
One of the roles of the board of directors is to provide advice on policies and strategies to management. This advice requires intellectual ability inherent in the board of commissioners, one of them is social capital. The study aims to determine the effect of social capital on the role of giving advice and counseling, as well as its impact on company performance. The population used is companies listed on the Indonesia Stock Exchange for the period 2008-2015. Based on purposive sampling, 150 observations are obtained. The hypothesis is tested using path analysis. This study provides evidence that social capital influences the role of advising, the role of advising influences the company performance; social capital does not directly affect the company's performance; and the role of advising mediates the influence of social capital on company performance. The results of this study indicate that the role of advising is needed in improving the company.

Keywords: Social Capital, Advising Role, Corporate Performance
\end{abstract}

\section{Introduction}

The main motivation of the company is to maximize the welfare of shareholders by increasing the value of the company. One effort to achieve prosperity can be done by managing the company appropriately. The company management includes internal and external control mechanisms. External control mechanisms can be achieved, among others, by hiring an external auditor to conduct an audit of the fairness of the presentation of financial statements. Meanwhile, the internal control mechanism can be fulfilled, among others, by hiring a board of commissioners.

The board of commissioners has various roles in the company. The role of the board of directors can be used to assess its effectiveness and contribute to influencing the performance of the company (Lawler et al., 2002). The effectiveness of the role of the board of commissioners can be achieved through high ability and integrity. Such qualifications are very necessary for companies in the form of Limited Liability Companies, especially companies that have public accountability.

Public companies in Indonesia are majority owned by controlling shareholders, and usually owned by the family. Companies that are mostly owned by families tend to have corporate governance issues and agency problems. When shareholders choose a board of commissioners, they tend to choose their own family members or someone who has a special relationship. Board of commissioners of family companies tends to be less independent and dominated by family members (Anderson and Reeb, 2003). According to agency theory, the board of commissioners is assumed to have the specific competencies and knowledge needed to carry out their role as an internal control mechanism. Consequently, there is a gap between the role expected to be achieved by the board of commissioners with their knowledge and experience (Kor and Sundaramurthy, 2009)

Public companies in Indonesia that are controlled by the family do not consider the board of commissioners' intellectual ability. This is consistent with the results of Darmadi's (2013) research that family companies tend to be relatively small companies, and usually do not pay attention to the capability of the board of commissioners in their recruitment. Most Indonesian public companies are owned by families with concentrated ownership, who tend to elect a board of commissioners from their own colleagues. Therefore, it is important to know the effectiveness of the role of the board of commissioners based on their intellectual capital. 
This research tries to identify the intellectual capital of the board of commissioners (board capital), which can contribute to the implementation of its role. As is known that the board of commissioners is a human who has the ability, knowledge, and experience, as well as good relations with internal parties and external parties of the company. The network built by the board of commissioners is social capital, which is expected to contribute to the implementation of advising roles and improve the performance of the company.

Resources Dependence Theory. The resource dependency theory identifies companies as open systems and depends on the contingencies of the external environment (Pfeffer and Salancik, 1978). There are several ways to minimize uncertainty and dependence on the environment, namely through the vertical merger of business integration, the board of commissioners, political action and executive succession. In terms of reducing dependence on the external environment and the need for critical resources, companies need the role of a board of commissioners, one of which is having access to resources.

The role of the board of commissioners in providing advice and resources includes the initiation of strategies, actively involved in decision making and following up strategic choices (Pugliese et al 2014). Various roles that can be carried out by the board of commissioners in the company such as giving an understanding that the board of commissioners can reduce dependence on the external environment and providing convenience in obtaining the critical resources needed.

Resources Based-View Theory. Based on the perspective of the Based-View Resources (RBV), differences in resources result in differences in performance achieved by the company. The position of company resources (strengths and weaknesses) is related to the profitability of the company (Wernerfelt, 1984). Intangible resources or invisible assets have the potential to create competitive advantages and become important factors in long-term success. Intangible resources are related to the intellectual capital of the company, especially intellectual capital owned by the board of commissioners in carrying out its role. The ability of the board of commissioners to integrate the interests of various stakeholders is needed to maintain the company's competitive advantage.

Social Capital. Social capital is a collection of actual and potential resources obtained through the relationship network that is owned by individuals or social units (Nahapiet and Ghosha, 1998). Social capital has been defined in various ways by a number of researchers (Adler and Kwon, 2002). Various definitions have implications that social capital is a company resource that is owned by individuals or social groups related to the network or relationships to be able to access external resources that are not owned by the company.

Advising Role. The board of commissioners has various roles in the company. The role of the commissioner is contingent on the internal and external characteristics of the company. The external environment makes the board of commissioners must optimize their role in establishing relationships with outside parties, in order to meet the needs of critical resources that are not available within the company.

Management experts focus on the main role of the board of directors in providing strategic advice to top management and promoting the company's reputation to external parties. Proponents of the resource dependency theory argue that the board of commissioners through its membership network with other organizations can assist companies in obtaining important resources such as capital and business cooperation. This perspective emphasizes the role of the board of commissioners in providing advice and counseling that helps company management in setting policies.

Firm Performance. Measuring company performance presents conceptual problems and methodologies. In addition to the various sizes and performance indicators, there are also many factors that can affect company performance. Factors that have relevance to the board of commissioners include size of the board of commissioners (Andres and Vallelado, 2008, Chin et al., 2004), composition of the board of commissioners (Andres and Vallelado, 2008, Coles et al., 2008, Hermalin and Weisbach, 1991, Kiel and Nicholson, 2003, Thomsen, 2005) and the effectiveness of the role of the board of commissioners. 
The company performance is very dependent on the utilization of resources owned by the company. If the company has resources that have a competitive advantage, it will achieve superior performance. This is consistent with the perspective of resources-based view theory, which views that corporate performance is the outcome of the use of internal and external resources of the company. Internal and external resources of the company, one of which is obtained from the intellectual capital of the board of commissioners. In addition to having the knowledge, skills, and expertise, the board of directors also plays a role in reducing dependence on the external environment, as well as providing facilities in obtaining external resources needed, in accordance with the views of resources dependence theory.

Hypothesis Development. Relates to the effectiveness of the role of the board of directors in improving company performance, it is necessary to consider the intangible resources attached to the individual board of commissioners. These resources are commonly called board capital intellectual capital, which among others is social capital. Social capital or relationship capital refers to an individual's ability to coordinate others in identifying opportunities and accessing resources through networking or relational (Burt, 1997).

Membership outside directors in various organizations (as a proxy for social capital) has a positive impact on company growth (Kor and Sundaramurthy, 2009). The results indicate that the increase in the level of sales of the company is in line with the increase in membership outside the director in various groups/organizations followed by the board of commissioners. The bond established by the commissioners of a particular company with the board of commissioners of other companies will add important information needed in the formulation of company policies (Carpenter and Westphal, 2001), thereby increasing the role of giving advice and counseling to corporate management.

Contrary, study Lin et al. (2014) provides evidence that the more positions held by the board of commissioners in other companies, will reduce the attendance of the board of directors at the meeting, thereby reducing the frequency of giving advice and counseling to management. Likewise, the results of the study by Fich and Shivdasani (2006) give the conclusion that the board of commissioners who concurrently hold positions at some companies leads to weak governance and corporate performance. Based on the above explanation, the following hypothesis is formulated:

H1: There is an influence of social capital on the advising role of the board of commissioners.

The provision of advice and counseling is given when the board of directors attends a meeting with the company management. This meeting is a media for expressing opinions and formulating important policies and strategies that must be carried out by the company. Andres and Vallelado (2008) and Liang et al. (2013) conducted research on banking companies, provided the view that the number of findings of the board of commissioners contributed to the improvement of performance. The presence of the board of commissioners at the meeting showed the commitment to achieve the company's goals.

The board of commissioners who provide advice (advisory board) has the best position in building trust with management and providing the time to focus on strategic problems (Faleye et al, 2013). Involvement in providing strategic advice to management shows the commitment of the board of directors to maintain the company's competitive position. Companies that successfully maintain their position will get appreciation from investors and further increase the value of the company. Based on the above explanation, the following hypothesis is formulated:

$\mathrm{H} 2$ : There is an influence of the advising role of the board of commissioners on company performance.

Resource-based view theory (RBV) considers that an organization or company is unique in that it is surrounded by diverse resources and capabilities (Barney, 1991). In the perspective of RBV, the unique resources of the company, especially those that are intangible, can create a sustainable competitive advantage. Intangible resources are more valuable, rarely possessed, not easily replicable and cannot be replaced, so they tend to differ from one company to other companies. This 
distinction produces competitive advantage and brings consequences to differences in outcomes produced.

Intangible resources inherent in the board of commissioners are able to produce competitive advantages. The board of commissioners has the capability in the form of intellectual capital that can support the success of the company. Some studies believe that intellectual capital is very important for companies because the level of human capital and high social capital will provide a high quality of service (Coleman, 1988, Nahapiet and Ghoshal, 1998).

The social capital of the board of directors reflected in the ability to establish relationships with external parties and the internal company will have an impact on the sustainability of the company. The board of commissioners who have been or are working with other companies will have broader experience and insight so that they can provide better advice to management and will further improve the company's performance. In accordance with the research of Kor and Sundaramurthy (2009) which gives results that social capital is built through internal relationships within the company, with business partners and client companies, will result in future company growth. Based on the above explanation, the following hypothesis is formulated:

H3: There is a direct influence of social capital on company performance.

H4: The advising role of the board of commissioners mediates the influence of social capital on company performance.

\section{Research Methodology}

The population of this study is all manufacturing companies listed the Indonesia Stock Exchange (IDX) in the period of 2008-2015. Population selection is only for manufacturing companies to avoid biased results that are due to differences in company characteristics. The selection of the observation period is because in October 2006 Indonesia just revised the principles and rules of governance of companies adopting from the OECD (Organization for Economic Co-operation and Development). The implementation of these principles and rules was effectively implemented in 2007 and 2008, so the impact of the implementation of the principles can be analyzed since 2008 (Ghofar, 2013). The observation period during the last year is used so that this research can obtain the most up-to-date data and can reduce the bias of the effects of certain events.

The determination of the sample is done by using purposive sampling method. The criteria are used as a basis for determining the sample of this study, first, the availability of the company's annual report 2008-2015 period; second, the presentation of the profile of the board of commissioners and the financial data in the company's annual report. Based on these criteria, 150 observations were obtained.

This study used secondary data, in the form of a summary of financial data, a summary of financial statements and an annual report of the company in 2008-2015. This study used an archival method to obtain data from the Indonesian Capital Market Directory (ICMD), the OSIRIS website, the company's website, and the IDX website. The data needed is related to the profile of the board of commissioners, accounting data, number of outstanding shares and stock market price data.

Social capital is one of the board's intellectual capital, which represents individual ability to extract benefits derived from social structures, interpersonal relationships, and membership in social organizations (Portes, 1998). Social capital can help to explain the difference in the success of a person or company in competitive competition. Social capital is goodwill available to individuals or groups.

Social capital is measured through network density, which describes the social relations of the board of directors and their external environment. Measurement of network density refers to the Reeb and Zhao (2013) as follows:

1) The board of commissioners concurrently serves as a board of commissioners in other companies. This indicator illustrates that if the board of commissioners of a particular company also holds concurrent positions as a board of commissioners in other companies, it 
is assumed that the board of commissioners has good relationship capital or can establish good relations with various parties.

2) The board of commissioners concurrently works in government. If the board of commissioners of a company also works in government, it is assumed that the board of commissioners can provide input or can influence government policy, especially policies that favor the company.

3) The board of commissioners becomes a member of professional organizations at the regional, national, or international level. The board of commissioners in the membership of professional organizations provides additional insights into the latest related issues. The participation of members of professional organizations in various forums will obtain up-todate information and also increase relations, which has an impact on increasing the knowledge and experience of the members.

These three qualifications are measured using a dummy variable, given a score of 1 if the board of commissioners has a qualification, and 0 if otherwise. After getting a qualification score for each board of commissioners, the scores are averaged for all commissioners in one company. Calculation of the network coverage level is as follows:

Network Density $=\sum$ qualification score for each board of commissioners in one company

Number of commissioners in one company

The role of advising and counseling by the board of commissioners is to provide independent input and analysis for company management. This role is usually carried out when attending the board of commissioners' meetings. The meetings are very important because they provide opportunities for all parties to express their opinions and conduct open discussions to obtain agreements for the progress of the company.

The frequency of the board meetings is often used as a measure of the success of the board of commissioner's advice and counseling role to company management (Liang et al., 2013, Xie et al., 2003). The more often the board of commissioners attending the meeting suggests that professional advice and advice regarding the company's policies and strategic decisions are conveyed. The presence of the board of commissioners at the meeting signals the magnitude of the board's commitment to increase the effectiveness of the role of giving advice and counseling. Proxy for the role variable of giving advice and counseling in this study uses the number of board meeting meetings for one year, both meetings within the board of commissioners and meetings with the company management (Vafeas, 1999).

This study uses financial measures to assess company performance. The measure of market performance used is Tobin's Q, as used by Brick Chidambaran (2010), Jermias and Gani, 2013, Lefort and Urzua, 2008). Tobin's Q emphasizes the assessment of future earnings that are expected by the company and is considered a forward-looking indicator that reflects the plan and current strategy (Kiel and Nicholson, 2003). Tobin's Q is the ratio of the company's market value to the replacement cost of assets. This study uses an alternative formula of Tobin's Q by Chung and Pruitt (1994); Villalonga and Amit (2006) as follows:

Market Value of Common Stock + Book Value of Preferred Stock + Book Value of Long-Term Debt

Tobin's $Q=$

Book Value of Total Assets

This study uses path analysis techniques that examine the magnitude of the contribution shown by the path coefficients in each path diagram of the causal relationship X1, X2 to Y. The steps to test path analysis are as follows:

a. Formulate structural hypotheses and equations

$\mathrm{X} 2=\rho \mathrm{x}_{1} \mathrm{X}_{2} \mathrm{X} 1+\varepsilon_{1}$

$\mathrm{Y}=\rho_{\mathrm{YX} 1} \mathrm{X} 1+\rho_{\mathrm{YX} 2} \mathrm{X} 2+\varepsilon_{2}$ 
b. Calculate the path coefficients based on the regression coefficients

1) Describe the full diagram, determine the sub-structures and formulate the structural equations that match the proposed hypothesis

2) Calculate the regression coefficients for the formulated structure

c. Calculate the path coefficients simultaneously by referring to the:

1) Rule of manual significance test (F-test)

2) The rule of significance test using the SPSS program with the probability is equal to or smaller than 0.05 .

d. Calculate individual path coefficients using a t-test.

Path model is found to explain the influence of the Social Capital (X1) on Company Performance (Y) both directly and through the Role of Suggestion and Counseling (X2) as a mediating variable with the following path equations:

$\mathrm{X} 2=\rho \mathrm{x}_{1} \mathrm{x}_{2} \mathrm{X} 1+\varepsilon$

$\mathrm{Y}=\rho_{\mathrm{YX} 1} \mathrm{X} 1+\rho_{\mathrm{YX} 2} \mathrm{X} 2+\varepsilon 2$

Notes:

$\mathrm{X} 1=$ Social Capital

$\mathrm{X} 2=$ The Role of Giving Advice and Counseling

$\mathrm{Y}=$ Company Performance

$\varepsilon=$ Contributing other variables (epsilon / error)

$\rho \times 1 \times 2=$ The path coefficient of X1 to X2

pyx $1=$ The path coefficient of $\mathrm{X} 1$ to $\mathrm{Y}$

pyx2 $=$ The path coefficient of X2 to $Y$

The path model above shows that equation (1) explains the hypothesis H1. Equation (2) explains the hypothesis $\mathrm{H} 2$ and $\mathrm{H} 3$. To explain $\mathrm{H} 4$, decomposition of the structure is carried out by multiplying the path coefficient sub-structure 1 with sub-structure 2 .

\section{Result and Discussion}

A summary of the hypothesis test is presented in the following table:

Table 1. Summary of the Results of Path Analysis

\begin{tabular}{|c|c|c|c|c|c|c|c|}
\hline \multirow{2}{*}{$\begin{array}{l}\text { Sub- } \\
\text { structure }\end{array}$} & \multicolumn{2}{|c|}{ Variable } & \multirow{2}{*}{$\mathrm{H}$} & \multirow{2}{*}{$\begin{array}{l}\text { Path } \\
\text { Coefficient } \\
(\rho)\end{array}$} & \multicolumn{2}{|c|}{$\begin{array}{l}\text { Hypothesis } \\
\text { testing }\end{array}$} & \multirow{2}{*}{ Conclusion } \\
\hline & Exogenous & Endogenous & & & $\begin{array}{l}\mathrm{t}- \\
\text { value }\end{array}$ & p-value & \\
\hline 1 & $\begin{array}{l}\text { Social } \\
\text { Capital (X) }\end{array}$ & $\begin{array}{l}\text { Meeting } \\
\text { Frequency } \\
(\mathrm{Y})\end{array}$ & $\mathrm{H}_{1}$ & 0,214 & 2,523 & 0.013 & Significant \\
\hline \multirow[b]{2}{*}{2} & $\begin{array}{l}\text { Social } \\
\text { Capital (X) }\end{array}$ & \multirow{2}{*}{$\begin{array}{l}\text { Company } \\
\text { Performance } \\
\text { (Z) }\end{array}$} & $\mathrm{H}_{2}$ & 0.123 & 1,458 & 0.147 & $\begin{array}{l}\text { Not } \\
\text { significant }\end{array}$ \\
\hline & $\begin{array}{l}\text { Meeting } \\
\text { Frequency } \\
(\mathrm{Y}) \\
\end{array}$ & & $\mathrm{H}_{3}$ & 0.277 & 3,285 & 0.001 & Significant \\
\hline
\end{tabular}

Based on the table above, it can be concluded that:

1) The $\rho$-value value of $\mathrm{H} 1$ is smaller than the alpha value $(0.013<0.05)$, therefore, there is an influence of Social Capital (X1) on the Role of Providing Advice and Counseling (X2)

2) The $\rho$-value of $H 2$ is greater than the alpha value $(0.147>0.05)$ hence, the influence of Social Capital (X1) on Company Performance (Y) is not significant 
3) The $\rho$-value of H3 is smaller than the alpha value $(0.001<0.05)$ so, there is an effect of the Role of Suggestion and Counseling (X2) on Company Performance (Y)

4) To find out $\mathrm{H} 4$ whether there is an indirect effect of Social Capital (X1) on Company Performance (Y) through the Role of Suggestion and Counseling (X2), the decomposition of the structure is conducted by multiplying the path coefficient of sub-structure 1 with substructure 2, as shown in the following table:

Table 2. Indirect Effect among Variables

\begin{tabular}{|l|l|l|l|l|}
\hline \multicolumn{1}{|c|}{ Indirect Effect } & Calculation & Results & t-value & Information \\
\hline $\begin{array}{l}\text { Social Capital (X) on } \\
\begin{array}{l}\text { Company Performance (Z) } \\
\text { through Meeting Frequency } \\
(Y)\end{array}\end{array}$ & $0.214 \times 0.277$ & 0.059 & 2,001 & Significant \\
\hline
\end{tabular}

The Influence of Social Capital (X1) on Company Performance (Y) through the Role of Giving Advice and Counseling (X2) is 0.059 and statistically significant with t-value greater than t-table $(2.001>1.978)$. The results show that the direct influence of Social Capital (X) on Company Performance (Y) is not significant. However, it turns out that the Role of Advice and Counseling (X2) is able to mediate the influence of Social Capital (X1) on Company Performance (Y) with the magnitude of the indirect effect of 0.059 .

The Influence of Social Capital on the Role of Providing Advice and Counseling of the Board of Commissioners. The results show that social capital influences the role of giving advice and counseling. Social capital as reflected in the number of connections/involvements in other organizations is seen as a board of commissioners with high-quality knowledge, thereby increasing the role of advice and counseling. This finding supports the study of Carpenter and Westphal (2001) which provides evidence that the bonds established by the board of commissioners with the boards of commissioners of other companies have a positive impact towards the formulation of company policies and strategies Communication between the board of commissioners will provide useful information about business practices, which in turn will expand the perspective and knowledge sufficient to contribute to the formulation of strategies. The rationale is that the board of commissioners obtains up-to-date and timely information from trusted sources. This argument refers to the socio-cognitive perspective, the involvement of the board of commissioners in social structure will have an impact on increasing the role of giving advice and counseling.

In addition to having good relationships with external parties, the board of commissioners must also be able to foster good relations with the company's internal. The strong interconnection between the board of commissioners and management to improve the quality of advice and counseling in this relationship makes the board feel comfortable when it comes to providing advice and counseling, because of the harmony between the board of directors and management (Young et al., 2001).

Meanwhile, this finding is not in line with the study of Fich and Shivdasani (2006), which concluded that the board of commissioners who has three or more positions as the board of commissioners in other companies, leads to weak corporate governance. The findings of the study support the busyness hypothesis which assumes that the more positions a person has, resulting in a person have to divide the time and effort (Lin et al., 2014). This creates difficulties in fulfilling adequate responsibilities as a board of commissioners so that the efforts made cannot be maximized. The Influence of the Role of Providing Advice and Counseling of the Board of Commissioners on Company Performance. The result shows that the role of giving advice and counseling to the board of commissioners affects company performance. The role of giving advice and counseling is reflected in the attendance of the board of directors at the meeting. This opportunity is used as a means to express opinions related to the formulation of strategies and company policies. The Board 
of Commissioners strives to determine policies that can benefit the company and minimize risk issues, so as to improve corporate performance.

The same thing was found in the study of Liang et al (2013), Lin et al. (2014) and Andres and Vallelado (2008) which provide evidence that the number of boardroom meetings has a significant impact on improving corporate performance. Board of Commissioners meeting is seen as an important aspect in corporate governance and is used as a moment to deliver a pen can, provide advice, and formulate a policy that wants strategies that can create competitive advantages for the company. This indicates that the role of giving advice and counseling works effectively and shows the proactive role of the board of directors in thinking about the progress of the company.

Meanwhile, other studies provide different results, the increase in the frequency of board meetings will be assessed less by the market, which is reflected in the decline in stock prices (Vafeas, 1999) This reflects that investors do not like the frequent meetings held by the board of commissioners, because they consider the limited time of the board of commissioners when the meeting is not used to exchange ideas that are useful between the board of commissioners and company management. The presence of the board of commissioners is only used to meet the regulations set by the regulator, and often the meeting attendance is represented by others.

The Influence of Social Capital on Company Performance. The results of the analysis show that social capital does not directly affect company performance. This is not in accordance with the study of Kor and Sundaramurth (2009), that the membership of the board of commissioners in other companies can increase the average sales growth of the company. This indicated that the more network connections owned by the board of commissioners, the broader the supervision, knowledge, and information possessed by the board of commissioners. Connections reflect the better capacity and access to information (Coles et al 2012). The information in question relates to market conditions, competitors, consumers, and suppliers of the company (Young et al., 2001). This information is needed in an effort to improve company performance.

This research is also not in line with the study of Fich and Shivdasani (2006) which investigated the relationship between the involvement of the board of directors in several busy directors and company performance. The results concluded that the board of commissioners who has three or more positions as a board of commissioners in another company cannot improve the company performance. This is because time is owned, and the efforts made by the board of commissioners must be allocated to several companies (Lin et al 2014). As a consequence, it has an impact on efforts that are not optimal and fulfillment of inadequate responsibilities, so that they cannot affect the company performance.

However, this study showed different findings when the role of giving advice and counseling mediated the influence of social capital on company performance. The results showed that there was an influence of social capital on company performance through the role of giving advice and counseling. This shows the importance of the role of giving advice and counseling that is supported by quality social capital in influencing company performance. The social capital owned by the board of commissioners has not been able to improve the performance of the company if it does not carry out the role of giving advice and counseling The involvement of the board of commissioners in other organizations or companies makes the board of commissioners have experience, broad insight, and improve communication skills, so that the board of commissioners can provide good advice in formulating company policies and strategies, which further improve the company's performance.

\section{Conclusion}

Companies in developing countries such as Indonesia are characterized to have less effective external governance and weak legal protection of investors. This condition requires an internal control mechanism, such as the existence of the board of commissioners. The existence of the board of commissioners can reduce dependence on the external environment because the board of 
commissioners is expected to provide critical resources that have not been yet in the company. One of the resources is an information resource that will be conveyed through an advising role as consistent with the resource dependence theory.

The implementation of the board's advising role requires the support of social capital. The broader relationships that are established by the board of commissioners, the better the insight experience and communication skills. This has an impact on the effectiveness of the role of advising and improving company performance. High social capital cannot affect company performance if the capability in social capital is not used to convey strategic advice that benefits the company. Thus, it can be concluded that the role of advising is very crucial in improving corporate performance.

\section{References}

ADLER, P. S. \& KWON, S.-W. 2002. Social Capital: Prospect for a New Concept. The Academy of Management Review, 27, 17-40.

ANDERSON, R. C. \& REEB, D. M. 2003. Founding-Family Ownership, Corporate Diversification, and Firm Leverage. Journal of Law and Economics, 46, 653-684.

ANDRES, P. D. \& VALLELADO, E. 2008. Corporate Governance in Banking: The Role of the Board of Directors. Journal of Banking \& Finance, 32, 2570-2580.

BARNEY, J. 1991. Firm Resources and Sustained Competitive Advantage. Journal of Management, $17,99-120$.

BRICK, I. E. \& CHIDAMBARAN, N. K. 2010. Board Meetings, Committee Structure, and Firm Value. Journal of Corporate Finance, 16, 533-553.

BURT, R. S. 1997. The Contingent Value of Social capital. Administrative Science Quarterly, 42, 339-365.

CARPENTER, M. A. \& WESTPHAL, J. D. 2001. The Strategic Context of External Network Ties: Examining The Impact of Director Appointments on Board Involvement in Strategic Decision Making. Academy of Management Journal, 4, 639-660.

CHIN, T., VOS, E. \& CASEY, Q. 2004. Levels of Ownership Structure, Board Composition, and Board Size Seem Unimportant in New Zealand. Corporate Ownership \& Control, 2, 119-128.

CHUNG, K. H. \& PRUITT, S. W. 1994. A Simple Approximation of Tobin's Q. Financial Management, 23, 70-74.

COLEMAN, J. S. 1988. Social Capital in the Creation of Human Capital. American Journal of Sociology, 94, 95-120.

COLES, J. L., DANIEL, N. D. \& NAVEEN, L. 2008. Boards: Does One Size Fit All? Journal of Financial Economics, 87, 329-356.

COLES, J. L., DANIEL, N. D. \& NAVEEN, L. 2012. Board Advising. Temple University and Drexel University.

DARMADI, S. 2013. Board Members' Education and Firm Performance: Evidence from a Developing Economy. International Journal of Commerce and Management, 23, 113-135.

FALEYE, O., HOITASH, R. \& HOITASH, U. 2013. Advisory Directors.

FICH, E. M. \& SHIVDASANI, A. 2006. Are Busy Board Effective Monitors? The Journal of Finance, 61, 689-724.

GHOFAR, A. 2013. Analysis of the Determinants and Effectiveness of Corporate Governance: A Contingency Theory Approach. Doctor of Business Administration, Victoria University.

HERMALIN, B. E. \& WEISBACH, M. S. 1991. The Effects of Board Composition and Direct Incentives on Firm Performance. Financial Management, Winter, 101-112.

JERMIAS, J. \& GANI, L. 2013. The Impact of Board Capital and Board Characteristics on Firm Performance. The British Accounting Review, XXX, 1-19.

KIEL, G. C. \& NICHOLSON, G. J. 2003. Board Composition and Corporate Performance: How The Australian Experience Informs Contrasting Theories of Corporate Governance. Corporate Governance, 11, 189-206. 
KOR, Y. Y. \& SUNDARAMURTHY, C. 2009. Experience-Based Human Capital and Social Capital of Outside Directors. Journal of Management, 35, 981-1006.

LAWLER, E. E., BENSON, G. S., FINEGOLD, D. I. \& CONGER, J. A. 2002. Corporate Boards: Keys to Effectiveness. Organizational Dynamics, 30, 310-324.

LEFORT, F. \& URZUA, F. 2008. Board Independence, Firm Performance and Ownership Concentration: Evidence from Chile. Journal of Business Research, 61, 615-622.

LIANG, Q., XU, P. \& JIRAPORN, P. 2013. Board Characteristics and Chinese Bank Performance. Journal of Banking \& Finance, 37, 2953-2968.

LIN, Y. F., YEH, Y. M. C. \& YANG, F. M. 2014. Supervisory Quality of Board and Firm Performance: a Perspective of Board Meeting Attendance. Total Quality Management, 25, 264-279.

NAHAPIET, J. \& GHOSHAL, S. 1998. Social Capital, Intellectual Capital, and Organizational Advantage. The Academy of Management Review, 23, 242-266.

PORTES, A. 1998. Social Capital: Its Origins and Applications in Modern Sociology. Annual Review of Sociology, 24, 1-24.

PUGLIESE, A., MINICHILLI, A. \& ZATTONI, A. 2014. Integrating Agency and Resource dependence Theory: Firm Profitability, Industry Regulation, and Board Task Performance. Journal of Business Research, 67, 1189-1200.

REEB, D. M. \& ZHAO, W. 2013. Director Capital and Corporate Disclosure Quality. J. Account. Public Policy, 32, 191-212.

THOMSEN, S. 2005. Corporate Governance as a Determinant of Corporate Values. Corporate Governance, 5, 10-27.

VAFEAS, N. 1999. Board Meeting Frequency and Firm Performance. Journal of Financial Economics, 53, 113-142.

WERNERFELT, B. 1984. A Resource-based View of The Firm. Strategic Management Journal, 5, 171-180.

XIE, B., DAVIDSON III, W. N. \& DADALT, P. J. 2003. Earnings Management and Corporate Governance: The Role of The Board and The Audit Committee. Journal of Corporate Finance, 9, 295-316.

YOUNG, M. N., AHLSTROM, D., BRUTON, G. D. \& CHAN, E. S. 2001. The Resource Dependence, Service and Control Functions of Board of Directors in Hongkong and Taiwanese Firms. Asian Pacific Journal of management, 18 223-244. 